\title{
KAJIAN EKRANISASI HAUTOT PÈRE ET FILS KARYA GUY DE MAUPASSANT
}

\author{
Nofia Kistianingsih dan Sunahrowi \\ Universitas Negeri Semarang \\ fiakistia@students.unnes.ac.id
}

\begin{abstract}
ABSTRAK
Penelitian ini bertujuan untuk membahas proses ekranisasi cerpen Hautot Père et Fils yang di dalamnya terdapat proses penambahan, penciutan, dan perubahan variasi. Ekranisasi adalah proses pelayarputihan. Penelitian ini merupakan penelitian kualitatif dengan analisis deskriptif. Objek penelitian ini berupa alur, penokohan, dan latar. Hasil penelitian terdapat 32 proses ekranisasi, dengan kategori aspek penciutan sebanyak 9, aspek penambahan sebanyak 7 , dan aspek perubahan variasi sebanyak 15 . Hasil penelitian tersebut menunjukan aspek perubahan variasi paling banyak terjadi. Perubahan variasi terbanyak pada unsur tokoh namun secara keseluruhan variasi yang dilakukan masih wajar karena tidak jauh melenceng dari penggambaran dalam cerpen. Sedangkan, pada unsur alur yang paling banyak proses ekranisasi dengan total 13. Dari perubahan alur tersebut dalam cerpen tidak menampilkan semua latar yang ada dalam film sehingga film hanya menampilkan latar-latar yang dianggap penting dan secara keseluruhan latar yang ditampilkan dalam film sudah mewakili cerita pada setiap bagian dalam film.
\end{abstract}

Kata Kunci: cerpen, ekranisasi, film

This study aims to discuss the process of ecranisation short story Hautot Père et Fils in which there is a process of adding, shrinking, and change variations. Ecranisation is the process of pelayarputihan. This research is qualitative research with descriptive analysis. The object of this research in the form of grooves, characterizations, and background. The results of the research 32 process ecranisation, with the category of aspect necking as much as 9, aspects the addition of as many as 7 , and the aspect of variation changes by as much as 15 . The results of these studies show aspects of change and variation occur most commonly. Variation changes the most in the elements of figures but the overall variation is still reasonable because it is not far deviated from the depiction in the short story. While, on the elements of groove that most process ekranisasi with a total of 13. From the change of the flow in the short stories do not display all of background there is in the film so that the film only displays the backgrounds that is considered important and the overall background shown in the film already represents the story in every part in the film.

Keywords: short story, ecranisation, film 
Dewasa ini sastra semakin berkembang, banyak karya sastra yang berubah menjadi sebuah karya yang lain. Sastra merupakan hasil cipta atau karya manusia yang dapat dituangkan melalui ekspresi yang berupa tulisan yang menggunakan bahasa sebagai mediumnya. Selain itu sastra juga merupakan hasil karya seseorang yang diekspresikan melalui tulisan yang indah, sehingga karya yang dinikmati mempunyai nilai estetis dan dapat menarik para pembaca untuk menikmatinya. Lewat sastra dapat diketahui pandangan suatu masyarakat, sastra juga mewakili kehidupan dalam arti kenyataan sosial (Rene Wellek dan Austinn Warren, 1995: 15). Dalam dunia sastra terdapat tiga genre karya sastra, yaitu puisi, drama, dan prosa.

Menurut Satinem, dalam buku Apresiasi Prosa Fiksi (2019:23), prosa dapat dikategorikan berdasarkan dua jenis, yaitu prosa lama dan prosa baru. Prosa lama juga sering diistilahkan dengan folklor atau cerita rakyat, yaitu cerita di kehidupan rakyat yang telah diwariskan dari generasi - generasi sebelumnya secara lisan. Sementara prosa baru merupakan karya prosa yang berkembang setelah mendapatpengaruh dari sastra atau kebudayaan asing. Beberapa jenis prosa baru, yaitu: cerpen, novel, novelet dan roman. Dalam penelitian ini penulis menggunakan cerpen sebagai sumber data. Cerita pendek yang biasa disingkat cerpen, dapat diartikan sebagai cerita yang berbentuk prosa pendek. Cerpen mempunyai efek tunggal serta tidak komplek. Cerpen umumnya menceritakan sedikit pengalaman yang paling menarik dalam kehidupan tokoh/pelaku utamanya.

Film menurut Effendy (1986:239) diartikan sebagai hasil budaya dan alat ekspresi kesenian. Adapun mengenai tumbuh kembangnya film sangat bergantung pada teknologi dan paduan unsur seni sehingga menghasilkan film yang berkualitas. Keberhasilan film banyak tergantung pada keharmonisan berbagai unsur pendukung film, seperti pengambilan gambar, penyusunan gambar, permainan aktor atau aktris, dan lain - lain.

Munculnya fenomena pengadaptasian novel ke bentuk film merupakan perubahan substansi dari wacana yang memunculkan istilah ekranisasi (Sunahrowi, 2017:160). Fenomena perubahan karya sastra ini telah terjadi sejak beberapa dekade. Ekranisasi adalah pelayarputihan atau pemindahan/pengangkatan sebuah novel ke dalam film (ecran dalam bahasa Perancis berarti layar). Pemindahan novel ke layar putih mau tidak mau mengakibatkan timbulnya pelbagai perubahan. Oleh sebab itu dapat dikatakan ekranisasi adalah proses perubahan yang bisa mengalami penciutan, penambahan, dan perubahan dengan sejumlah variasi. Yang berarti karya sastra lebih rinci dalam menggambarkan suatu peristiwa dalam cerita dibanding film dan ternyata bukan hanya pada cerita, alur, penokohan, latar, dan suasana saja yang terjadi perubahan tetapi tema atau amanat novel saja telah berubah dalam film (Erneste, 1991). Terdapat perbedaan yang mendasar antara film dan novel jika dilihat dari unsur yang diutamakan. Film lebih mengutamakan aspek audio visual untuk memanjakan mata dan telinga penontonnya sehingga suasasna dan perasaan-perasaan yang 
dibangun tokoh dapat digambarkan lebih mudah dengan akting pemain dan set ruang. Dalam novel, rangkaian kata menjadi satu-satunya alat untuk menggambarkan seluruh cerita (Saputra, 2009).

Mengadaptasi karya sastra menjadi sebuah film belakangan ini tidak saja dilakukan terhadap novel, tetapi juga terhadap karya sastra lain yaitu cerita pendek atau disingkat cerpen. Terdapat beberapa cerpen yang telah diadaptasi ke dalam film seperti karya Guy de Maupassant. Selain ke dalam film, adapula serial televisi yang bernama Chez Maupassant di France 2. Total serial ini terdiri dari 24 episode salah satunya pada Maret tahun 2007 terdapat serial berjudul Hautot Père et Fils berdurasi 30 menit yang juga di adaptasi dari cerpen dengan judul yang sama. Awalnya, cerpen Hautot Pére et Fils dipublikasikan dalam surat kabar di Prancis yang bernama L'Écho de Paris tanggal 5 Januari 1889. Setelah itu, cerpen tersebut dipublikasikan bersama cerpen lain dari Guy de Maupassant kedalam series La Main Gauche pada tahun yang sama.

Pamusuk Eneste juga mengatakan pemindahan dari novel ke film berpotensi mengalami berbagai macam perubahan. Pertama, Film yang hanya berdurasi kurang lebih sembilan puluh sampa seratus menit yang artinya tidak semua hal yang diungkapkan dalam novel akan dijumpai pula dalam film. Sebagian alur, tokoh, latar ataupun unsur lainnya yang ada dalam novel tidak akan ditemui dalam film. Biasanya pembuat film (penulis skenario atau sutradara) telah memilih bagianbagian atau informasi-informasi yang dianggap penting untuk ditampilkan sehingga hal itu disebut dengan penciutan.

Selanjutnya, terdapat penambahan yang biasanya dilakukan oleh penulis skenario atau sutradara karena mereka telah menafsirkan novel yang akan mereka filmnya sehingga akan terjadi penambahan di sanasini. Penambahan misalnya terjadi pada alur, penokohan, latar atau suasana. Penambahan dalam proses ekranisasi tentu mempunyai alasan. Misalnya, dikatakan bahwa penambahan itu penting jika dilihat dari sudut filmis. Selain itu, penambahan dilakukan karena masih relevan dengan cerita secara keseluruhan (Eneste, 1991 : 64-65)

Ekranisasi juga memungkinkan terjadinya variasi-variasi tertentu dalam film. Walaupun terjadi variasi - variasi antara novel dan film, biasanya tema atau amanat dalam novel masih tersampaikan setelah difilmkan. Karena perbedaan alat-alat yang digunakan, terjadilah variasi-variasi tertentu di sana-sini. Film pun mempunyai waktu putar yang amat terbatas, sehingga tidak semua hal atau persoalan yang ada dapat dipindahkan ke dalam film. Oleh karna itu amanat dalam novel masih dapat ditemukan di film hanya saja bentuk dan pengungkapan nya berlainan. Proses ekranisasi ini merupakan perubahan variasi.

METODE

Penelitian ini adalah penelitian kualitatif, yaitu penelitian yang menghasilkan data deskriptif berupa kata-kata tertulis atau lisan dari orang-orang dan perilaku yang diamati (Bogdan dan Taylor dalam Moleong, 2016:4). Selain itu, penelitian ini menggunakan metode 
deskriptif komparatif yakni merupakan metode gabungan antara deskripsi, analisis dan juga bandingan. Penelitian komparatif adalah sejenis penelitian deskriptif yang ingin mencari jawab secara mendasar tentang sebab-akibat, dengan menganalisis faktor - faktor penyebab terjadinya ataupun munculnya suatu fenomena tertentu (Nazir 2014:46). Penelitian ini mengidentifikasi dan menjelaskan tentang ekranisasi cerita pendek ke film Hautot Père et Fils.

Sumber data penelitian ini adalah cerita pendek Hautot Père et Fils dalam series La Main Gauche karya Guy de Maupassant, diterbitkan pada tahun 1889 dan film yang berjudul sama yaitu Hautot Père et Fils disutradarai oleh Marc Rivière pada tahun 2007. Menurut Sangidu (2004:61) data penelitian sastra adalah "Bahan penelitian, atau lebih tepatnya bahan jadi penelitian yang terdapat dalam karya satra yang diteliti". Jadi, data dalam penelitian ini berupa bagian - bagian kalimat yang mengandung penciutan, penambahan dan perubahan variasi cerpen ke film dalam segi (1) alur, (2) tokoh, dan (3) latar.

PEMBAHASAN
Ekranisasi menyebabkan perubahan yaitu berupa penciutan, penambahan dan perubahan variasi sesuai dengan unsur - unsur instrinsik karya sastra. Ketiga hal tersebut akan dibahas dibawah ini:

\section{Alur}

Alur merupakan unsur fiksi yang penting, banyak orang yang menganggapnya sebagai yang terpenting diantara berbagi unsur fiksi yang lain. Alur mengandung unsur jalan cerita atau tepatnya sebagai jalannya peristiwa demi peristiwa yang susul menyusul. Dalam pemilihan peristiwa ada beberapa adegan yang dirasa tidak penting untuk ditampilkan sehingga sutradara menghilangkan adegan-adegan dalam cerita. Namun, pada film Hautot Père et Fils tidak ada penciutan signifikan yang mempengaruhi perubahan jalan cerita dari awal adegan yang berupa perkenalan tokoh sampai akhir film. Selain penciutan, pada penambahan alur yang berupa tidak adanya adegan dalam cerpen tetapi dalam film ditampilkan oleh sutradara juga tidak banyak mengalami proses ekranisasi.

Adapun perubahan variasi paling banyak mengalami proses ekranisasi sebab sutradara yang memberi pengaruh atau memiliki sudut pandang terhadap karyanya berdasarkan interprestasi dan imajinasinya dalam cerpen yang diekranisasinya. Berikut salah satu beberapa perubahan variasi pada konflik cerita:

On le dévêtit, et on vit une plaie affreuse par où les intestins sortaient. Alors, après qu'on l'eut ligaturé tant bien que mal..." (HpetF page 39)

"Mereka melepas pakaiannya dan mereka melihat luka yang menakutkan, di mana usus keluar. Kemudian, setelah membalutnya cara terbaik yang mereka bisa..."

Pada kutipan diatas, dijelaskan bahwa mereka melepaskan pakaian Hautot dan lukanya telah dibalut sebelum mereka pulang kerumahnya. Namun, terdapat perbedaaan pada film Hautot masih mengenakan pakaian nya dan luka tembaknya yang berada diperut tidak diperban.

"César Hautot passa le reste du jour à pleurer. Il dormit à peine la nuit 
suivante et il se sentit si triste..." (HpetF page 43)

"César Hautot menghabiskan sisa hari nya dengan menangis. Ia hampir

tidak tidur malam berikutnya dan dia merasa begitu sedih..."

Perubahan variasi selanjutnya setelah dari pemakaman ayahnya seperti pada kutipan tersebut César yang seharusnya menangis. Namun, dalam film César berada di ruang makan sambil memakan sup yang disediakan oleh Céleste. Ia tidak nafsu makan sehingga sup tersebut tidak habis walaupun itu makanan kesukaan nya seperti yang dikatakan Céleste.

Proses ekranisasi alur pada film Hautot Père et Fils tidak banyak mengalami perubahan yang berbeda. Dimulai dari perkenalan tokoh yang sedang makan bersama dirumah Hautot sebelum mereka pergi untuk berburu. Lalu, Hautot yang tidak sengaja tertembak dari peluru Tuan Bermont yang mengenai perutnya sehingga mengeluarkan banyak darah dan segera membawa Hautot pulang untuk diobati oleh dokter. Menuju konflik ketika Hautot mengungkapkan keinginan terakhirnya dan harus ditepati oleh César anaknya bahwa ia mempunyai simpanan bernama Caroline Donet semenjak istrinya meninggal. Selanjutnya tahap penyelesaian atau ending ketika César menemui simpanan ayahnya dan membuat perjanjian akan bertemu setiap hari Kamis dirumah Caroline Donet. Total keseluruhan hasil ekranisasi alur yaitu 13 perubahan namun hal tersebut tidak banyak berbeda sebab masih dalam menceritakan maksud keseluruhan isi cerpen.

\section{Penokohan}

Penokohan berfungsi untuk menunjang cerita dan alur atau dengan kata lain, "penokohan bertugas menyiapkan atau menyediakan alasan bagi tindakan-tindakan ternetu yang terjadi dalam keseluruhan novel. Bentuk penokohan yang paling sederhana adalah pemberian nama. Setiap sebutan adalah sejenis cara memberi kepribadian, menghidupkan (Rene Wellek dan Austinn Warren, 2016 : 264). Walau demikian, tentu tidak semua tokoh-tokoh novel mempunyai nama. Melalui sifat atau watak yang dimiliki tokoh-tokoh novel, pembaca dapat mengerti mengapa suatu tindakan atau kejadian terjadi.

Dalam aspek penciutan tokoh hanya ditemukan 1 penciutan yaitu dihilangkannya tokoh pengawal yang bersama Tuan Bermont. Saat Tuan Bermont mengunjungi rumah Hautot dan membawa sendiri tas penembakan nya terjadi perubahan variasi alur. Oleh sebab itu secara otomatis adanya penciutan tokoh yang seharusnya terdapat sosok pengawal yang membawakan tas tersebut namun pada awal adegan film tersebut tidak ada.

“...et hurlaient à la vue des carnassières poilées par le garde et des gamins." (HpetF page 36)

"melolong saat melihat tas penembakan yang dibawa oleh pengawal dan anak laki-laki."

Selain itu, penambahan tokoh juga terdapat 1 penambahan yaitu Céleste yang berperan sebagai pembantu dikeluarga Hautot dan wanita tersebut cukup sering muncul. Ia pertama kali muncul saat menyiapkan makanan untuk Hautot dan teman - temannya. 
Monsieur Haurot : Merci Céleste de prendre soin de mes dents

Tuan Haurot : Terima kasih Celeste untuk merawat gigi saya

Kutipan tersebut merupakan percakapan dari film ketika Céleste pertama kalinya muncul. Terlihat dalam film ia adalah sosok yang mengerti Hautot. Tokoh Céleste merupakan tokoh tambahan karena dalam cerita tidak diceritakan sama sekali sosok sepertinya.

Perubahan variasi tokoh merupakan proses ekranisasi yang paling banyak ditemukan yaitu sebanyak 7 perubahan. Perubahan variasi tokoh dilihat dari perbedaan yang dideskripsikan dalam cerpen ke bentuk visualiasi yang tidak sesuai. Misalnya, salah satu tokoh utama César dalam cerpen digambarkan lebih mudah sedih terutama saat ayahnya yaitu Hautot terluka ia menangis melihatnya dan setelah dimakamkan ia sangat sedih. Tidak hanya pada César, tokoh Hautot dalam cerpen dideskripsikan oleh penulis bahwa ia terlihat sombong. Tetapi dalam film sosok Hautot tidak berbicara dengan sombong karena segala sesuatu nya yang dia punya melainkan terlihat seperti orang yang ramah sebab ia menjadi pendengar cerita - cerita dari temannya. Selain itu, tokoh pendukung lainnya seperti Tuan Bermont karakternya dalam film yang cukup banyak bicara dan ia memiliki janggut pun tidak disebutkan demikian.

\section{Latar}

Latar adalah tempat berpijak atau bertumpunya cerita, alur dan tokoh-tokoh novel. Ia berusaha menjelaskan keseluruhan lingkungan (waktu dan tempat). Dalam analisis ini menggunakan dua jenis latar, yang pertama latar tempat yang merupakan tempat atau keterangan mengenai tempat kejadian terjadinya cerita ataupun keberadaan pelaku dalam cerita. Unsur tempat yang digunakan mungkin berupa tempattempat dengan nama tertentu, inisial tertentu, mungkin lokasi tertentu tanpa nama jelas. Kedua, terdapat juga latar waktu yaitu keterangan waktu yang menunjukan kapan sebuah peristiwa atau kejadian dalam cerita.

Perubahan pada latar yang cukup menonjol ketika Hautot terluka akibat adanya penciutan alur maka aspek lainnya seperti latar juga terpengaruhi.

"On le tira du fossé, on le dévêtit, et on vit une plaie..." (HpetF page 39)

"Mereka menariknya dari parit, mereka melepas pakaiannya dan mereka melihat luka..."

Dalam cerita dijelaskan saat Hautot tertembak oleh Tuan Bermont dan jatuh ke parit seperti pada kutipan diatas. Namun, dalam film tidak ada latar parit tersebut saat Hautot telah tertembak.

"Il mourut vers minuit, après quatre heures de tressaillements indiquant d'atroces souffrances" (HpetF page 43)

"Dia meninggal sekitar tengah malam, setelah empat jam kejang yang menunjukkan penderitaan yang menyiksa"

Adegan selanjutnya dalam film Hautot langsung dibawa pulang kerumahnya. Namun, dalam film tidak dijelaskan berapa lama waktu 
yang telah berlalu, sedangkan dicerita dijelaskan secara spesifik waktu yang berlalu saat Hautot akan meninggal yaitu empat jam kemudian. Selain itu, pada kutipan diatas dijelaskan bahwa ia meninggal sekitar tengah malam tetapi dalam film terlihat sekitar sore hari karena masih adanya cahaya yang cukup terang hal tersebut menunjukan perubahan variasi latar waktu. Kelebihan dari sebuah cerpen atau novel yaitu setiap cerita dijelaskan dengan sangat terperinci.

Berikut perbandingan proses ekranisasi yang terjadi pada film dan cepen dalam aspek latar:

\begin{tabular}{|l|l|}
\hline Latar tempat dalam cerpen & Latar tempat dalam film \\
\hline Halaman rumah & Halaman rumah \\
\hline Ruang makan & Ruang makan \\
\hline Semak-semak pemburuan & Semak-semak pemburuan \\
\hline Parit & - \\
\hline Kamar Hautot & Kamar Hautot \\
\hline Makam & Makam \\
\hline Ladang & Ladang \\
\hline Hôtel des Bon-Enfants & - \\
\hline Rouen & Rouen \\
\hline Rumah nomor 18 & - \\
\hline Dapur rumah Caroline & - \\
\hline
\end{tabular}

Tabel 1. Perbandingan Ekranisasi Latar Tempat

\begin{tabular}{|l|l|}
\hline Latar waktu dalam cerpen & \multicolumn{1}{|c|}{ Latar waktu dalam film } \\
\hline Siang hari & Siang hari \\
\hline Hari minggu & Hari minggu \\
\hline Tengah Malam & - \\
\hline Hari selasa & Hari selasa \\
\hline Pada pukul 10.00 & - \\
\hline Hari Kamis & Hari kamis \\
\hline
\end{tabular}

Tabel 2. Perbandingan Ekranisasi Latar Waktu

Berdasarkan hasil analisis tentang proses ekranisasi pada unsur alur, tokoh, dan latar dalam cerita pendek Hautot Père et Fils karya Guy de Maupassant ke bentuk serial televisi dengan 
judul yang sama pada tahun 2007 disutradarai oleh Marc Rivière, dapat disimpulkan sebagai berikut:

Proses ekranisasi alur pada film Hautot Père et Fils kategori aspek penciutan alur sebanyak 3 penciutan, kategori aspek penambahan alur sebanyak 4 penambahan, dan untuk kategori aspek perubahan bervariasi alur sebanyak 6 perubahan bervariasi dengan total keseluruhan hasil ekranisasi alur yaitu 13. Proses ekranisasi alur tidak banyak perubahan yang sangat berbeda sebab masih dalam menceritakan maksud keseluruhan isi novel nya.

Proses ekranisasi penokohan pada film Hautot Père et Fils kategori aspek penciutan tokoh sebanyak 1 penciutan, kategori aspek penambahan tokoh sebanyak 1 penambahan, dan untuk kategori aspek perubahan bervariasi tokoh sebanyak 7 perubahan bervariasi dengan total keseluruhan hasil ekranisasi penokohan yaitu 9. Dari tokoh-tokoh yang terdapat dalam cerpen dan film, dapat dilihat banyak nya perubahan variasi tokoh sebab dalam proses ekranisasi hal tersebut penting jika dilihat dari sudut filmis.

Proses ekranisasi latar pada film Hautot Père et Fils kategori aspek penciutan latar sebanyak 5 penciutan, kategori aspek penambahan latar sebanyak 2 penambahan, dan untuk kategori aspek perubahan bervariasi latar sebanyak 2 perubahan bervariasi dengan total keseluruhan hasil ekranisasi latar yaitu 9. Alur dalam film tidak menampilkan semua latar yang ada dalam novel. Ada banyak latar yang dipotong misalnya latar tempat saat Hautot tertembak, dan latar waktu yang jelas ketika Hautot meninggal.

\section{DAFTAR PUSTAKA}

Erneste, P. 1991. Novel dan Film. Jakarta: Nusa Indah.

Estyaji, D. 2017. Ekranisasi Cerpen Filosofi Kopi Dalam Kumpulan Cerpen Filosofi Kopi Karya Dewi Lestari Ke Dalam Film Filosofi Kopi Sutradara Angga Dwimas Sasongko. E-Jurnal Bahasa dan Sastra Indonesia UNY, 615-628.

Moleong, L. J. 2016. Metode Kualitatif. Bandung: Remaja Rosdakarya.

Nazir, M. 2014. Metode Penelitian. Bogor: Ghalia Indonesia.

Saputra, H. S. 2009. Transformasi Lintas Genre Dari Novel ke Film, Dari Film ke Novel. Humaniora, 41-55.

Satinem. 2019. Apresiasi Prosa Fiksi: Teori, Metode dan Penerapannya. Yogyakarta: Deepublish.

Sunahrowi. 2017. Ekranisasi: Karya Sastra dan Film. Yogyakarta: Pustaka Senja.
Wellek, R., \& Warren, A. 2016. Teori Kesusastraan. Jakarta: Gramedia. 